\title{
Aphrodisiac Effects of Areca Fruit in Erectile Dysfunction Rat Model
}

\author{
Muhammad Totong Kamaluddin ${ }^{1}$, Nita Parisa ${ }^{1 \#}$, Salni ${ }^{2}$ \\ ${ }^{1}$ Pharmacology Department, Faculty of Medicine Sriwijaya University, Indonesia \\ ${ }^{2}$ Biology Department, Faculty of Medicine Sriwijaya University, Indonesia \\ \#Correspondence Email :nitaparisa@unsri.ac.id \\ Received : June $17^{\text {th }} 2019$ \\ Accepted :August $17^{\text {th }} 2019$
}

\begin{abstract}
\section{Background}

Erectile Dysfunction (ED) cases are quite high in both women and men and increase with age. Areca fruit, ginseng and purwoceng are plants that have been traditionally used to increase male vitality.

Objective

To analyze the efficacy of areca fruit, ginseng and purwoceng in sexual activity and hormonal level in erectile dysfunction rat model.

Methods

This is in vivo experimental research study with pre and post-test control group design located in the laboratory of animal house and the biomolecular laboratory Faculty of Medicine Sriwijaya University. The subjects of this study were albino rats (Rattus norvegicus), Wistar strains, divided into 6 groups are negative control, Sildenafil, Areca Fruit Extract (AFE) $50 \mathrm{mg} / \mathrm{kgBW}$, AFE $100 \mathrm{mg} / \mathrm{kgBW}$, Combination of Areca Fruit, Ginseng and Purwoceng (AGP) $50 \mathrm{mg} / \mathrm{kgBW}$ and AGP $100 \mathrm{mg} / \mathrm{kgBW}$. Female rat was injected by giving 500 $\mathrm{mg} / 100 \mathrm{~g}$ of subcutaneous progesterone and $10 \mu \mathrm{g} / 100 \mathrm{~g}$ of BB benzoate 48 hours before mating so that female mice enter the esterus phase.

Results

It was found that Combination of Areca fruit, Ginseng and Purwoceng (AGP) group 50mg/kgBW significantly improved testosterone levels compared to sildenafil, while single areca fruit (AFE) dose $50 \mathrm{mg} / \mathrm{kgBW}$ increased FSH and LH levels as well as sildenafil statistically.

Conclusion
\end{abstract}

The combination of areca fruit, ginseng and purwoceng is effective as treatment for erectile dysfunction.

Keywords: areca fruit, erectile dysfunction, FSH, ginseng, LH, purwoceng, testosteron

\section{Introduction}

Sexual needs support happiness for a partner throughout his life. Then every disturbance of sexual life will surely interfere with the happiness and life of the couple. ${ }^{1}$ Various diseases such as illness, age, tiredness and life stress often cause disruption in sexual life so that the couple's inability to achieve sexual satisfaction appears. This disorder is called sexual dysfunction. 
The results of research by Edward O Laumann, et al (1999) conducted in the United States stated that $14.8 \%$ of men aged 18-59 years experience a lack of sexual desire. Whereas $30.6 \%$ experience a climax that is too fast which can be caused by premature ejaculation. As many as $10.2 \%$ feel difficulty in achieving or maintaining an erection, commonly called erectile dysfunction (ED). ${ }^{2}$ Most sexual dysfunction in men lately is premature ejaculation and erectile dysfunction, whereas in women is desire dysfunction and arousal. ${ }^{3}$.

Sildenafil is an oral medication to treat erectile dysfunction, which is quite successful, but there are still many side effects. Sildenafil increases sensitivity to light, blurred vision, color blindness (blue-green) in 3-10\% of patients. In addition, for patients who consume drugs that contain organic ingredients, if taken together with Sildenafil will increase the risk of systemic hypotension that endangers the lives of consumers. ${ }^{4}$ So that another alternative treatment is needed using traditional medicine. Areca fruit (Areca cathecu) is a plant that has been traditionally used to increase male vitality. In addition purwoceng plants (Pimpinella pruatjan) and ginseng (Javanese Som) are also known to the community for their ability to spur spermatogenesis and efficacy to increase male vitality. ${ }^{5}$

The combination of several types of herbs has been started by the ancient Indonesian ancestors with a powerful herb known as "herbal medicine". In this study, it was further developed a combination of 3 types of herbs that would be tested experimentally at the preclinical level, followed by the determination of the active molecular formula and could be accounted for and finally formulated in a product formulation of a tested herbal drug (fitopharmaca) which could be consumed accordingly the indication.

\section{Method}

The research design is an in vivo experimental study with pre and post test with control group. The subject of study was Male Rattus norvegicus Wistar strain, divided into 6 groups (5 rats each group) were negative control, Sildenafil, Areca Fruit Extract (AFE) $50 \mathrm{mg} / \mathrm{kgBW}$, AFE $100 \mathrm{mg} / \mathrm{kgBW}$, Combination of Areca Fruit, Ginseng and Purwoceng (AGP) 50 $\mathrm{mg} / \mathrm{kgBW}$ and AGP $100 \mathrm{mg} / \mathrm{kgBW}$. It was injected by testosterone $5 \mathrm{mg} / \mathrm{KgBW}$ for 21 days to induce erectile dysfunction. The female rats was injected injected by giving $500 \mathrm{mg} / 100 \mathrm{~g}$ of subcutaneous progesterone and $10 \mu \mathrm{g} / 100 \mathrm{~g}$ of BB benzoate 48 hours before mating so that female mice enter the esterus phase. 
Simplisia was obtained from Gandus Plantations and Natural Herbal Medika Yogyakarta. Aquous extract is made by infusion method from simplicia from each medicinal plant, and evaporated it by rotary eveaporator.

The parameters examined include testosteron, FSH and LH by the sandwich ELISA method. Examination of testosteron, FSH and LH levels was carried out 2 times, namely pretreatment and post-treatment .

\section{Result}

\section{Effectiveness on Testosteron, FSH and LH Level Post Treatment}

Testosteron, FSH and LH levels were examined before and 14 day post treatment, results were obtained there are significant differences in testosterone, FSH and LH levels before and after treatment in all groups $(\mathrm{p}<0,05)$.

However, the highest testosterone levels were found in the AGP $50 \mathrm{mg} / \mathrm{kgBW}$ group, the highest FSH level in the AFE 50mg/kgBW group and the highest LH level increase in the AFE $50 \mathrm{mg} / \mathrm{kgBW}$ group.

Table 1. Effectiveness on Testosteron, FSH and LH Level Post Treatment

\begin{tabular}{ccccc}
\hline Parameter & Group & Pre Treatment & $\begin{array}{c}\text { Post } \\
\text { Treatment }\end{array}$ & p value \\
\hline Testosteron & Negative Control & $0.43 \pm 0.016$ & $0.517 \pm 0.018$ & 0.001 \\
& Sildenafil & $0.41 \pm 0.007$ & $0.624 \pm 0.034$ & 0.000 \\
& AFE 50mg/kgBW & $0.43 \pm 0.019$ & $0.639 \pm 0.044$ & 0.000 \\
& AFE 100mg/kgBW & $0.44 \pm 0.023$ & $0.626 \pm 0.011$ & 0.000 \\
& AGP 50mg/kgBW & $0.42 \pm 0.010$ & $0.873 \pm 0.017$ & 0.000 \\
& AGP 100mg/kgBW & $0.41 \pm 0.016$ & $0.789 \pm 0.019$ & 0.000 \\
\hline FSH & Negative Control & $0.33 \pm 0.019$ & $42.47 \pm 1.175$ & 0.000 \\
& Sildenafil & $0.31 \pm 0.012$ & $10.43 \pm 1.175$ & 0.000 \\
& AFE 50mg/kgBW & $0.33 \pm 0.030$ & $84.97 \pm 1.749$ & 0.000 \\
& AFE 100mg/kgBW & $0.34 \pm 0.016$ & $38.47 \pm 1.094$ & 0.000 \\
& AGP 50mg/kgBW & $0.32 \pm 0.023$ & $59.03 \pm 3.439$ & 0.000 \\
& AGP 100mg/kgBW & $0.31 \pm 0.028$ & $75.22 \pm 2.112$ & 0.000 \\
\hline LH & Negative Control & $0.24 \pm 0.031$ & $1.468 \pm 0.141$ & 0.000 \\
& Sildenafil & $0.21 \pm 0.008$ & $2.397 \pm 0.227$ & 0.000 \\
& AFE 50mg/kgBW & $0.22 \pm 0.012$ & $2.493 \pm 0.221$ & 0.000 \\
& AFE 100mg/kgBW & $0.23 \pm 0.015$ & $2.013 \pm 0.126$ & 0.000 \\
& AGP 50mg/kgBW & $0.20 \pm 0.039$ & $1.788 \pm 0.149$ & 0.000 \\
& AGP 100mg/kgBW & $0.24 \pm 0.020$ & $2.013 \pm 0.170$ & 0.000 \\
\hline
\end{tabular}

a Paired T Test 


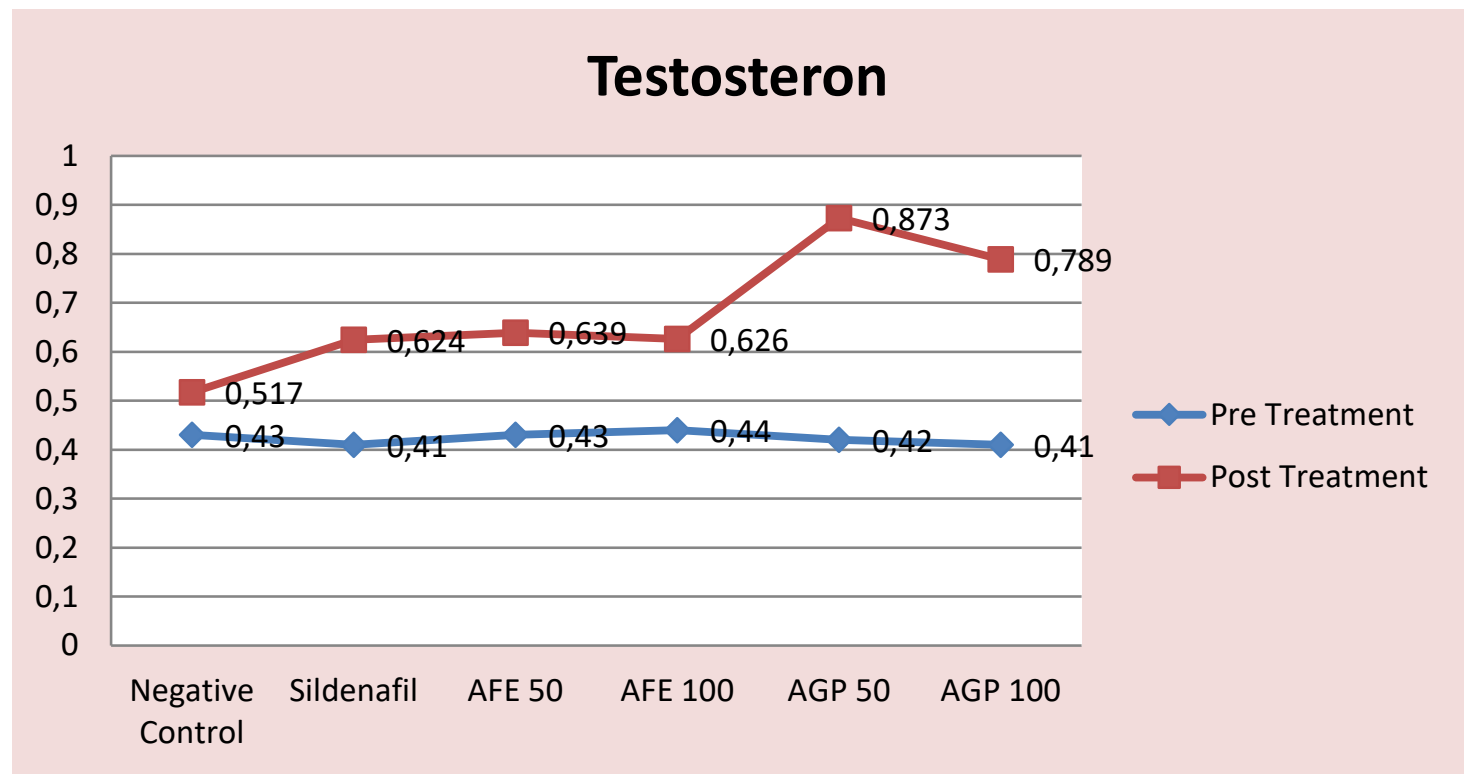

Figure 1. Testosteron Level Pre and Post Treatment

\section{FSH Level}

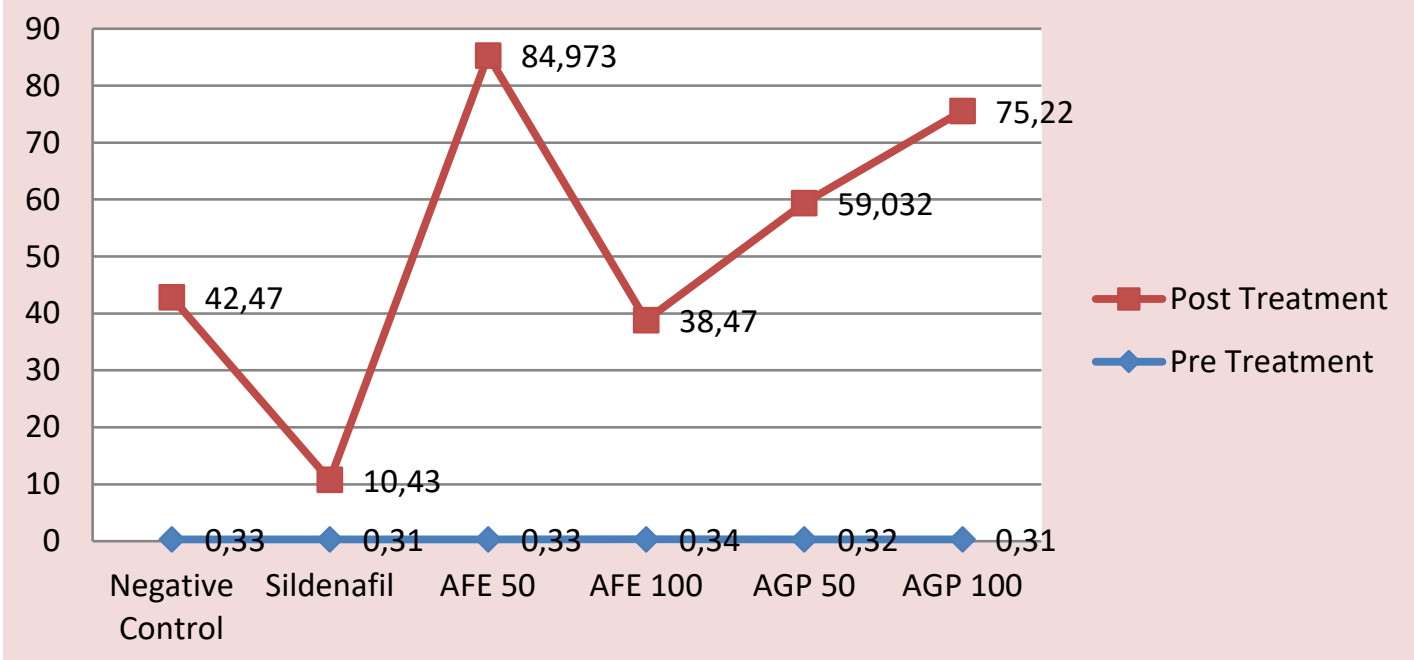

Figure 2. FSH Level Pre and Post Treatment 


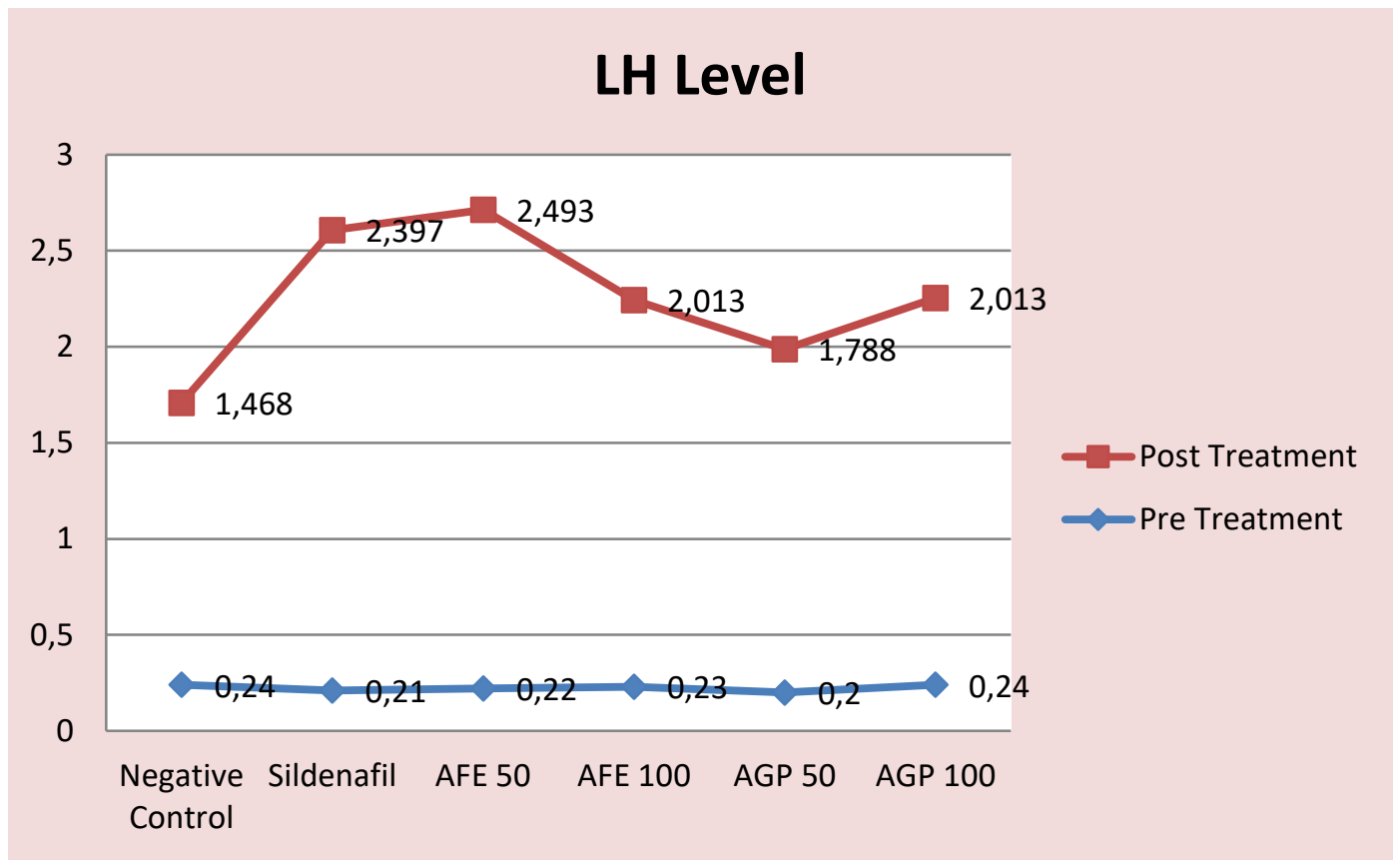

Figure 3. LH Level Pre and Post Treatment

\section{Comparison of Effectiveness on Testosteron, FSH and LH Level Post Treatment}

\section{Testosteron Level}

Testosteron, FSH and LH levels between groups were then compared. By conformity test using Post hoc showed that there was no difference in testosterone levels in the sildenafil group with AFE 50mg/kgBW and AFE $100 \mathrm{mg} / \mathrm{kgBW}$.

Table 2. Conformity Test of Testosteron Level Post Treatment

\begin{tabular}{|c|c|c|c|c|c|c|}
\hline & Negative & Sildenafil & AFE 50 & AFE 100 & AGP 50 & AGP 100 \\
\hline Negative & & 0.000 & 0.000 & 0.000 & 0.000 & 0.000 \\
\hline Sildenafil & 0.009 & & 0.946 & 1.000 & 0.000 & 0.000 \\
\hline AFE 50 & 0.000 & 0.946 & & 0.971 & 0.000 & 0.000 \\
\hline AFE 100 & 0.000 & 1.000 & 0.971 & & 0.000 & 0.000 \\
\hline AGP 50 & 0.000 & 0.000 & 0.992 & 0.000 & & 0.000 \\
\hline AGP 100 & 0.000 & 0.000 & 0.000 & 0.000 & 0.000 & \\
\hline
\end{tabular}

${ }^{\mathrm{a}}$ Post Hoc Test 
FSH Level

In addition, there were results of differences in FSH levels between the sildenafil group and all treatment groups, both single areca fruit or combination of areca fruit, ginseng and purwoceng.

Table 3. Conformity Test of FSH Level Post Treatment

\begin{tabular}{|c|c|c|c|c|c|c|}
\hline & Negative & Sildenafil & AFE 50 & AFE 100 & AGP 50 & AGP 100 \\
\hline Negative & & 0.000 & 0.000 & 0.039 & 0.000 & 0.000 \\
\hline Sildenafil & 0.000 & & 0.000 & 0.000 & 0.000 & 0.000 \\
\hline AFE 50 & 0.000 & 0.000 & & 0.000 & 0.000 & 0.000 \\
\hline AFE 100 & 0.039 & 0.000 & 0.000 & & 0.000 & 0.000 \\
\hline AGP 50 & 0.000 & 0.000 & 0.000 & 0.000 & & 0.000 \\
\hline AGP 100 & 0.000 & 0.000 & 0.000 & 0.000 & 0.000 & \\
\hline
\end{tabular}

${ }^{\mathrm{a} P o s t}$ Hoc Test

\section{LH Level}

The next parameter is the LH level. In this study, there was no difference LH level between the sildenafil and AFE $50 \mathrm{mg} / \mathrm{kgBW}$. In addition, there was no difference in LH levels in the AFE $100 \mathrm{mg} / \mathrm{kgBW}$ with AGP $50 \mathrm{mg} / \mathrm{kgBW}$ and AGP $100 \mathrm{mg} / \mathrm{kgBW}$.

Table 4. Conformity Test of LH Level Post Treatment

\begin{tabular}{|c|c|c|c|c|c|c|}
\hline & Negative & Sildenafil & AFE 50 & AFE 100 & AGP 50 & AGP 100 \\
\hline Negative & & 0.000 & 0.000 & 0.000 & 0.081 & 0.001 \\
\hline Sildenafil & 0.000 & & 0.953 & 0.024 & 0.000 & 0.024 \\
\hline AFE 50 & 0.000 & 0.953 & & 0.003 & 0.000 & 0.003 \\
\hline AFE 100 & 0.001 & 0.024 & 0.003 & & 0.365 & 1,000 \\
\hline AGP 50 & 0.081 & 0.000 & 0.000 & 0.365 & & 0.365 \\
\hline AGP 100 & 0.001 & 0.024 & 0.003 & 1.000 & 0.365 & \\
\hline
\end{tabular}

${ }^{\mathrm{a}}$ Post Hoc Test

\section{Discussion}

In this study showed that there was no difference in testosterone levels in the sildenafil group with Areca fruit extract (AFE) $50 \mathrm{mg} / \mathrm{kgBW}$ and $100 \mathrm{mg} / \mathrm{kgBW}$ This result accordance with Reena's research which shows that ethanol extract of young areca fruit seeds (Areca cathecu) at a dose of $150 \mathrm{mg} / \mathrm{kg}$ BW increases libido/sexual activity in male white rats. ${ }^{6}$ However, the highest testosterone levels were found in the combination of Areca fruit, Ginseng and Purwoceng (AGP) group 50mg/kgBW, this condition shows the effectiveness of the 
combination of Areca fruit, Ginseng and Purwoceng (AGP) group 50mg/kgBW is better in increasing testosterone levels than sildenafil.

In a condition of decreased libido (sexual arousal) testosterone deficiency occurs or in postmenopausal conditions (women) or andropause (men over 60 years) characterized by a decrease in some sex hormones including testosterone. ${ }^{7,8,9}$. Areca fruit (Areca cathecu) is a plant that has been traditionally used to increase male vitality. In addition purwoceng plants (Pimpinella pruatjan) and ginseng (Javanese Som) are also known to the community for their ability to spur spermatogenesis and efficacy to increase male vitality. ${ }^{5}$

For the FSH and LH parameters, the highest increase in the Areca fruit extract (AFE) $50 \mathrm{mg} / \mathrm{kgBW}$ group and statistically there was no difference in LH level between sildenafil and Areca fruit extract (AFE) 50mg/kgBW. However, for FSH levels all groups were different from sildenafil.

\section{Conclusion}

Combination of Areca fruit, Ginseng and Purwoceng (AGP) group 50mg/kgBW significantly improved testosterone levels compared to sildenafil, while single areca fruit (AFE) dose $50 \mathrm{mg} / \mathrm{kgBW}$ increased FSH and LH levels as well as sildenafil statistically.

\section{References}

1. De Vries, M.K. (2009) Sex, Money, Happiness and Death; The Quest for Autenticity, Palgrave Macmillan, 1th Edition, Macmillan Publishers Limited, London, 2009 978-0-230-577902-3

2. Laumann E.O., Paik A., Rosen R.C. (1999) Sexual dysfunction in the United States: prevalence and predictors, JAMA. 1999 Feb 10;281(6):537-44.

3. McCabe M,P.,, Sharlip I,D., Lewis R., Atalla E., Balon R., Fisher A,D., Laumann E.O, Lee S,W., Segraves R,T. (2016) Incidence and Prevalence of Sexual Dysfunction in Women and Men: A Consensus Statement from the Fourth International Consultation on Sexual Medicine 2015, J Sex Med. 2016 Feb;13(2):144-52. doi: 0.1016/j.jsxm.2015.12.034.

4. Ishikura, F., Beppu,S., Hamada,T., Khandheria,B.K., Seward,J.B., Nehra, A., Effects of Sildenafil Citrate (Viagra) Combined With Nitrate on the Heart, Circulation. 2000;102:2516-2521

5. Suhartinah, (2012) EfekSpermatogenesis dan Afrodisiaka Herba Purwoceng (Pimpinella alpina K.D.S.) asal Dieng pada Tikus Putih Jantan Galur Wistar, Jurnal Biomedika, Universitas Setia Budi, ISSN 2302-1306 di akses Agustus 2012 dari http://biomedika.setiabudi.ac.id

6. Reena, R., Anthikat,N., Micheal,A., Ignacimuthu,S. (2013) Aphrodisiac Effect of Areca catechu L.and Pedalium murex in Rats, Journal of Men's Health. November 2013, 10(2): 65- 70. doi:10.1016/j.jomh.2012.07.003.

7. Rebecca, G., Briganti, E., Tran, J., Wolfe, R., Davis, S.R. (2003). "Transdermal testosterone therapy improves well-being, mood, and sexual function in premenopausalwomen." Menopause. 10 (5):3908.doi:10.1097/01.GME.0000060256.03945.20. PMID 14501599

8. Brown, G.A., Vukovich, M.D., Martini, E.R., Kohut, M.L., Franke, W.D., Jackson, D.A., King, 
ISSN 25980580

D.S. (2001). "Effects of androstenedione-herbal supplementation on serum sex hormone concentrations in 30- to 59-year-old men". Int J Vitam Nutr Res. 71 (5): $293-$ 301. doi: 10.1024/0300-9831.71.5.293. PMID 11725694.

9. Gray, P.B., Singh, A.B., Woodhouse, L.J., Storer, T.W., Casaburi, R., Dzekov, J., Dzekov, C., Sinha-Hikim, I., Bhasin, S. (2005). "Dose-dependent effects of testosterone on sexual function, mood, and visuospatial cognition in older men". J Clin Endocrinol Metab. 90 (7): 383846. doi:10.1210/jc.2005-0247. PMID 15827094 